\begin{tabular}{|l|l|l||}
\hline \multicolumn{2}{|c|}{ PublisherInfo } \\
\hline \hline PublisherName & $:$ & BioMed Central \\
\hline \hline PublisherLocation & $:$ & London \\
\hline \hline PublisherImprintName & $:$ & BioMed Central \\
\hline \hline
\end{tabular}

\title{
Freedom of Information
}

\begin{tabular}{||l|l|l||}
\hline \multicolumn{2}{|c|}{ ArticleInfo } \\
\hline \hline ArticleID & $:$ & 21 \\
\hline \hline ArticleDOI & $:$ & $10.1186 /$ ar-2000-2-webreport0013 \\
\hline \hline ArticleCitationID & $:$ & 0013 \\
\hline \hline ArticleSequenceNumber & $:$ & 17 \\
\hline \hline ArticleCategory & $:$ & Web Report \\
\hline \hline ArticleFirstPage & $:$ & 1 \\
\hline \hline ArticleLastPage & $:$ & 2 \\
\hline \hline & & RegistrationDate : 2000-10-13 \\
ArticleHistory & $:$ & OnlineDate \\
\hline \hline ArticleCopyright & $:$ & Current Science Ltd2000-10-13 \\
\hline \hline ArticleGrants & $:$ & \\
\hline \hline ArticleContext & $:$ & 130752211 \\
\hline \hline
\end{tabular}




\section{Overview}

BioMed Central publishes peer-reviewed research accross all areas of biology and medicine. All research published on the site is accessible free of charge.

\section{Details}

All research published by BioMed Central is peer-reviewed by external reviewers and published quickly online. BioMed Central articles are cited in PubMed (http://arthritis-research.com/PubMed/ index.cfm) and are available in full through the PubMed Central permanent archive (http://pubmedcentral.nih.gov). The peer review process is speeded up by the use of a web-based system for referees to view manuscripts and feed back comments to authors. Medical papers will be published with reviewers comments and the suthor's response.

\section{Other comments}

BioMed Central is supported by many leading scientists and clinicians around the world. "BioMed Central promises to deliver all primary research without financial and copyright barriers and deserves all our support. Free access to research and the right to distribute work among colleagues will allow scientists to participate in a truly worldwide community of scholars."Professor Marc Kirscnher, University of Harvard.

\section{References}

1. BioMed Central. [http://BioMedCentral.com] 